\title{
The Use of WhatsApp in Collaborative Learning to Improve the Reading Skill Among University Students: A Case Study of Saudi Students of English at the University of Jeddah
}

\author{
Nasser Alasmari ${ }^{1}$ \\ ${ }^{1}$ Department of English \& Translation, University of Jeddah, Jeddah, Saudi Arabia \\ Correspondence: Nasser Alasmari, Department of English \& Translation, University of Jeddah, Jeddah, Saudi Arabia. \\ E-mail: nsalasmari@uj.edu.sa
}

Received: December 17, 2019

Accepted: December 29, 2019

Online Published: December 31, 2019

doi:10.5430/irhe.v4n4p36

URL: https://doi.org/10.5430/irhe.v4n4p36

\begin{abstract}
Researchers have advocated collaborative learning and largely reported its evidenced advantages in learning a language. They have emphasized that students working collaboratively tend to learn language better and retain knowledge longer than when learning through any other instructional format (Johnson, Johnson, \& Holubec, 1993). In addition, these researchers questioned which tool is most effective in the successful implementation of this kind of learning. In this respect, technology has been recommended as an effective tool that leads to higher language achievements (Almekhalfi \& Almeqdadi, 2010). In more particular terms and given its popularity, the WhatsApp messenger application has been strongly advocated and highlighted as one of the most effective media for instruction that significantly contributes to the success of language learners (Cakir, 2015, as cited in Ta'amneh, 2017).

Aiming to add to the growing literature about the integration of WhatsApp in education, this paper measures the impact of this application's use for improving the reading skill of 30 Saudi male learners of English as a foreign language, as well as identifying their perceptions towards the English language_learning experience after implementing WhatsApp in their learning. Data were gathered via pre- and post-tests as well as through a focused group interview. The findings proved the significant association between the use of WhatsApp and the improvement of the reading skills of the participants, who articulated a favourable attitude towards the use of WhatsApp as a tool for language learning.
\end{abstract}

Keywords: collaborative learning, reading, WhatsApp, improvement, foreign language

\section{Introduction}

A skill is defined as the ability to perform something effectively. Swimming or dancing, for example, are skills that people come to use after acquiring them. According to Husain (2015), language is basically a skill and not a content-based subject such as mathematics, geography, or history. It is meant to help its users express their thoughts and feelings. The same author added that language is further divided into four sub-skills, namely listening, speaking, reading, and writing. The ability to use all these skills fluently and accurately is known as language proficiency. Indeed, and within educational boundaries, language proficiency has become a highly demanded skill when it comes to EFL (English as a foreign language) education. This pressure is attributed to the fact that English has become a global lingua franca and a hyper-central language that millions of students and teachers around the world are learning in order to achieve different goals (Al-Issa, 2017). Therefore, a bulk of research has been carried out to answer the pressing question of what makes English language learners proficient, and many answers have been suggested relating proficiency to different variables. Researchers, scholars, and academicians have proposed a focus on renewing our understanding of learning styles, identifying the best qualities of language teachers, eliciting the students' perceptions, and determining their needs. They have also recommended the implementation of technology in collaborative learning environments and enlarged on its merits in terms of better language attainment and higher proficiency levels, which will constitute the focus of this paper. 


\section{Literature Review}

\subsection{Collaborative Learning}

Collaborative learning refers to an educational approach to teaching and learning that describes the intellectual efforts made by students, or students and teachers together, to create and develop knowledge (Kane \& Harms, 2005). The literature is filled with evidence of the importance of collaborative learning as a superior instructional method compared to its traditional counterpart because of the strong evidence that supports the significant association between collaborative learning and higher language proficiency levels. Zahnle (2016), for instance, believed that students can easily overcome their language-learning problems and achieve higher attainment levels if they find themselves in a "safe" environment that motivates them to pursue and construct knowledge. Johnson et al. (2000) emphasized that such an environment can be possible once teachers introduce collaborative learning strategies into the curriculum. As a matter of fact, the incorporation of collaborative learning is aided through the harness of technology so as to generate an engaging, creative, and collaborative learning experience. To put it in Arya's (2017) words, "effective communication, interaction and collaboration, and creativity are all vital development tools that can be enhanced through a digital learning environment" (p. 1).

\subsection{Collaborative Learning, English Language Proficiency, and Technology}

Evidently, we are now at a time in human development where digital technologies are significantly contributing to language learning in many parts of the world (Chapelle, 2003). Many scholars and education leaders have highlighted its effectiveness in language learning and consider computers and related internet technology as vital educational tools and innovations (Forteza \& Ortiz, 2015). Pelgrum (2001) also claimed that ICT (Information and Communication Technology) is not only the "backbone" of the information age, but a "sounding tool" that helps bring educational alterations that will turn learners into "productive knowledge workers" (cited in Cavas et al., 2009, p. 20). Almekhalfi and Almeqdadi (2010) went further to assert that technology is a "cornerstone" to improve students' language performance.

The strong relationship between technology and academic achievements justifies the deep concern of many educational institutions to incorporate technology into the classroom in recent years. Therefore, technology has been the subject of interest, and its introduction into the language classroom may yield positive language-learning outcomes (Ismail et al., 2010). Similarly, Wainwright (2013) pointed out that technology in education gets plenty of hype. She encouraged its introduction into the classroom and considered it a "great way" to guarantee diversity in learning styles. Mustafa et al. (2012) also stressed the importance of exploiting the "plethora of resources provided by computer" (p. 426) in learning a second language. Cavas et al. (2009) further highlighted the strong effect technology has on education, as "it provides enormous tools for enhancing teaching and learning" (p. 21).

Based on the above-mentioned claims, language learning is significantly improved when using ICT. The recent trend in ICT is the utilization of social networking like Facebook, Twitter, and WhatsApp. Boyd (2003) defined social networks as the different applications that facilitate interactions and group-forming. They give users the chance to receive feedback. Such programs, according to Cetinkaya (2017), have become phenomenally popular among young people and a prevalent element in their everyday lives. Therefore, incorporating them within the educational realm has become inevitable. The same author asserted that such digital tools and ICT facilities as emails, wikis, online games, and social networking can be employed effectively in classrooms. This ignites research to be carried out in order to examine the usability and the effects of these messaging applications on language learning. The question that may be raised, in this respect, is the type of application that is most effective for meeting educational goals.

\subsection{WhatsApp as a Social Network}

WhatsApp is an encrypted instant messaging application that is free to download for smartphones. As the name suggests, it sends messages, videos, audio files, and images over the internet. This app has become one of the most popular messaging apps available and was launched in 2009 According to Ramakrishnan (2017), this app is "in vogue," as it has attracted over 1.2 billion users and is ranked first when compared to its competitors (Facebook, Twitter, Blackberry, Line, WeChat). This may justify the focus that has been centred on this app and the suggestion for it to be incorporated in education. A review of the literature revealed that WhatsApp is one of the most effective tools to be adopted in language learning classrooms. In fact, this app "is doing a yeoman service to the students to develop competency in foreign language" (Ramakrishnan, 2017, p. 1). Ajid et al. (2018) shared the same view and related that "there is an emerging evidence that these Apps [referring to WhatsApp] have a significant potential to support the learning process and has substantial implications on pedagogies. Language learners have a more opportunity to listen and speak that language in their classroom with their friends and teacher" (p. 31). It has opened 
up new opportunities for interaction and collaboration between teachers and learners in which the former may create a group or a forum and instruct the latter to join and interact. This forum is supposed to include a variety of learning activities, thus offering learners more opportunities to explore WhatsApp in English, which would help them improve their language skills.

\subsubsection{WhatsApp as a Collaborative Tool}

Cetinkaya (2017) highlighted WhatsApp as a collaborative tool for learning a language. When used for educational purposes, this messaging device helps learners communicate in the target language, interact with one another for help, ask questions, share information, and discuss solutions. Rambe and Bere (2013) examined students' collaboration through the use of WhatsApp as a learning tool. Their findings indicated a positive impact of this application on the participants' use of the English language through discussion and interaction which, according to the authors, were richer and more flexible than in traditional lecturing (cited in Ta'amneh, 2017). Within similar lines of thought, Amry (2013) carried out a study whose aim was to determine the impact of using WhatsApp on the learning activities of university students. To this end, the author established a comparison between face-to-face and online learning and came to the conclusion that the group that uses e-learning achieves better academic outcomes. This foregrounds WhatsApp as an effective tool to learn a foreign language, a result that was confirmed by Alfaki and Alharthy (2014), who asserted that learning a language through social networks proves to be more successful than traditional learning. They added that adopting collaborative tools such as WhatsApp helps to improve students' foreign language attainment.

\subsubsection{The Effect of WhatsApp Usage on English Language Skills}

Ta'amneh (2017) tried to determine the effect of using WhatsApp on English learning among Saudi students at Taibah University. The results of his study revealed that "using WhatsApp messenger affected the learning process positively" (p. 20). He attributed this finding to the fact that WhatsApp helps learners retain information at their own pace. When the students using this app have plenty of time to see their teachers' explanations and comments as well as their classmates' enquiries, this creates a sense of belonging and encourages them to interact and participate in the discussions. This, in turn, helps the learners to gain a deeper and better understanding of the topic. The same author went further to claim that WhatsApp took over the traditional way of learning, as it makes the learners feel more comfortable and motivated when learning a language. Ajid et al. (2018) came to the same conclusion and reported that "WhatsApp is beneficial to students" knowledge of the language" (p. 33). Kheryadi (2018) confirmed that "it is likely true that the use of such media can engage learners in learning English and improve their skills" (p. 2).

An interesting point was raised by Justina (2016) in terms of the effect of WhatsApp usage on language learning. She insisted that WhatsApp does not directly impact the language skills but enhances the learners' motivation, which is a key variable that directs them in how to perform and develop a language skill (Hohn, 1995, as cited in Justina, 2016). For this reason, this author proclaimed that the introduction of such messaging applications as WhatsApp in education would nurture motivation which, in turn, brings out the best in students and maximizes their use of their language skills.

Reading. According to Justina (2016), WhatsApp provides language learners with a sufficient scope to practice reading. The extensive employment of this medium helps students strengthen their reading skills. In their article entitled "What's up with WhatsApp?," Church and de Oliveira (2013) explored the relationship between the use of WhatsApp and proficiency in language learning and found a positive association between the two variables. Indeed, the students reached a higher level in reading comprehension after utilizing WhatsApp. The authors attributed this finding to the learners' motivation to use mobile technologies.

Cetinkaya (2017) observed that the teachers attempted to improve their learners' reading skills by using WhatsApp to send a selection for reading, be it a short story or a text about a particular topic. They then instructed the students to read and understand it before going through the different reading tasks that followed. The results of this study indicated that the skill of reading is reinforced, especially if the texts are supported with images. These shared texts and images contribute to the improvement of reading skills. Muthaiyan and Kanchana (2016) confirmed the students' higher motivation for reading when using WhatsApp, which resulted in enhancements to their reading skills. Equally, Plana et al. (2013) asserted that using WhatsApp-mediated language activities enhanced the learners' reading habits and their willingness to read more (cited in Alshammari et al., 2017).

Listening. The employment of WhatsApp can also develop students' listening skills. By sending audio recordings, teachers expose their learners to comprehensible input when they ask them to take notes while listening. Teachers also share English conversation videos and instruct learners to listen to them and offer comments. Additionally, and 
in order to raise their students' interest in listening, teachers provide their learners with pre-listening activities on WhatsApp (Cetinkaya, 2017).

Speaking. Jafari and Chalak (2016) conducted a study to explore the effect of using WhatsApp on the development of speaking skills. Most of the subjects in their study who used WhatsApp outperformed those who did not. They considered the utilization of WhatsApp to be an opportunity for learners to speak English. After choosing a particular theme, learners can record their voices to convey their comments, for example, or register an oral reading of a story.

To enhance their learners' speaking skills, teachers may instruct the learners to re-record their voices as many times as they wish until they feel satisfied to share it with the other group members on WhatsApp. As such, the speaking skill is practiced, and better language gains are expected. In the same vein, Justina (2016) pointed out that some students rarely speak to their teachers in their usual classes but find WhatsApp useful even to joke in English, as they are not inhibited by the language-learning conditions, as is the case in conventional settings.

\subsection{Teachers' and Learners' Perceptions of WhatsApp}

Teachers hold a favourable attitude towards this messaging application. Cetinkaya (2017) declared that the "WhatsApp application is one of the most favored mobile applications" (p. 60). Cakir (2015) conducted a study to elicit the attitudes of English teachers towards the use of WhatsApp as an instructional tool in teaching and found, similarly, that most of the respondents viewed the use of this mobile app favourably. They claimed that the employment of WhatsApp makes the English language teaching and learning experience more meaningful and communicative. They also added that their learners became more motivated and interested in the lesson when instructed to use WhatsApp (cited in Ta'amneh, 2017).

Cetinkaya (2017) carried out a study to identify learners' views about the educational use of WhatsApp. The students in this study opted for the incorporation of this messaging application in the classroom and defended its positive impact on their motivation and willingness to study. They further stated that in addition to the conscious process, learning can take place unconsciously when using WhatsApp and, accordingly, higher academic achievements are realized. The same result was found by Kheryadi (2018), who argued that by constantly receiving messages from the other members through the flow of conversation in a group chat, the learners try to understand the information and subsequently join in the given learning activity: "This subconscious process gives a wide chance for them to learn and practice using the target language naturally" (p. 3).

Furthermore, Ajid et al. (2018) found that learners held a positive attitude towards WhatsApp and strongly supported the idea of formally using it in the process of language learning. They believed that "the integration of WhatsApp into their education will be easy, fun and useful. Students get positive feelings and intentions regarding the possible use of WhatsApp in their formal learning" (p. 33). When eliciting the students' views of WhatsApp integration in formal education, Cetinkaya (2017) observed a strong will from the participants to see the application implemented as a learning tool. One of the informants in this study related that, "if used for other lessons, [WhatsApp] could be more enjoyable ... I could learn easily" (p. 67).

In the same vein, Hamad (2017) investigated the perceptions of a group of learners at King Kahlid University towards the use of WhatsApp and its effects on developing their language skills. A majority of the subjects agreed on the positive effects of this application. In effect, these subjects acknowledged that their speaking and reading skills developed significantly by sending recorded speeches to the group and reading their classmates' comments and responses. They also mentioned the improvement they noticed in the skill of listening when they listened to the videos and audio recordings shared in the forum as well as to their peers' and instructors' recordings.

In another respect, Kant (2018) explored the attitudes of two groups of students from two colleges in Darbhanga city of India towards the use of WhatsApp. He stated that the learners who express a positive attitude are those who frequently use technology in general and are very familiar with it. The rest of the participants in the study had an average attitude. He also found no gender-based differences in perceptions of WhatsApp's employment in education.

\subsection{The Educational Attributes of WhatsApp}

Regarding the advantages of this app and others, Crescent and Lee (2011) pointed out that the introduction of these devices would make a difference in the educational environment and ease the move from the total dependence on the classroom as the sole setting where learning takes place to new ways of learning, thus providing both instructors and learners with more options to learn and communicate anytime and anywhere (cited in Ta'amneh, 2017). The same idea of easy accessibility was articulated by Cetinkaya (2017), who added, concerning the positive attributes of this program, that it creates an atmosphere of cooperation and collaboration between learners, as it increases their social 
interaction and removes social barriers. It also raises their interest and motivation for learning. Learners are provided with feedback and support from their peers and teachers, and they become more active in their learning.

Similarly, Hamad (2017) considered the use of WhatsApp in education "an experience to share" and listed a number of its advantages. She reported that in addition to the development of language skills that many researchers had cited, using WhatsApp increased learners' motivation, self-confidence, and feelings of security, as they were no longer afraid of making mistakes when using the language in a non-restricted learning environment. She also noted that the students felt interested in initiating and participating in group discussions using the target language. With the teacher monitoring the group, learners were immersed in an English-speaking environment that would definitely enhance their proficiency level. The use of such a device helped the learners reduce their anxiety and encouraged them to take part in learning English: "When students feel relaxed and safe among friends their tension decreases. For that case, they are much likely to participate more and learn more" (Mwakapina \& Mhandeni, 2016, p. 38).

Mwakapina and Mhandeni (2016) aimed to study what learners consider to be the advantages of WhatsApp and challenges in utilizing it. They came up with the following notes. First, this application affords equal and fair chances for all the learners to participate in a forum, unlike in conventional classrooms where only a limited number of learners have opportunities to partake in discussions because of the restricted timeframe and large class sizes. Second, the use of WhatsApp saves time, as it broadens the coverage of many topics at a time. The topics which are not well-covered in conventional classes can be caught up on later via WhatsApp, where each student can participate at the time that suits him or her.

Equally, WhatsApp makes it possible to consult instructors or teachers at any time for anything discussed in class. In universities, these instructors have hectic timetables, and their availability is not guaranteed. Accordingly, WhatsApp makes teachers straightforwardly accessible and available at any time.

However, this experience is not without shortcomings. To name a few, not all the learners participate in group discussions, nor do they exploit the input offered. Others do not feel engaged or involved; they can remove themselves from the group at any time, or they simply copy and paste. Added to this, some students may lack focus, and their attention is not guaranteed (Hamad, 2017).

\subsection{Statement of the Problem}

WhatsApp is a popular messaging application that is widely used among the younger generation, especially Universitystudents. In Saudi Arabia, this application is the most commonly used social media tool, with almost nine million users (according to Global Media Insight, 2016), thus eclipsing other social media applications such as Facebook, Skype, and Snapchat (Alshammari et al., 2017). As such, its integration in the English language-learning process has been the concern of various researchers in recent years. In the Saudi context, few studies have focused on such a pressing issue and were undertaken at the university level. This paves the way for and justifies the conduct of the present work, the aim of which is to investigate the impact of this application's use on improving the reading skills of 30 Saudi male EFL learners and to identify their perceptions towards the English language experience after implementing WhatsApp in their learning. It seeks to answer the following questions:

1. What is the effect of using WhatsApp on the reading skill of the Saudi learners of Business at the University of Jedddah?

2. What are their perceptions towards the learning of English through the use of WhatsApp?

\section{Methodology}

As aforementioned, the aim of this paper is to evaluate students' learning experiences after using WhatsApp in EFL settings, which mainly involved the reading skill. Therefore, and in order to reach this aim, a full semester-long (12 weeks) experience case study was undertaken, during which WhatsApp was used as a supplementary medium of instruction to develop the students' language skills.

\subsection{Population}

The population of the study consisted of two groups of Saudi male students, currently studying English as a foreign language in Khulais Branch at the University of Jeddah in Saudi Arabia. The two groups were selected by random sampling out of all the students and designated as (a) an experimental group, which involved 30 members and was taught English using WhatsApp; and (b) a control group, which was made up of 30 students and taught in the conventional way. The participants were all approximately 18 years old and largely shared the same social and educational background. 
It is worth noting that all the subjects in the experimental group owned smartphones, onto which the WhatsApp application was downloaded. The choice of male students as the only participants was due to cultural and religious considerations.

\subsection{Data Collection Tools}

The first tool for data collection was a focused group interview (Appendix A), the main aim of which was to investigate the subjects' readiness and anxiety about using WhatsApp to perform the reading activities at home. The same focused group interview was performed again in order to elicit the students' views about the experience of using WhatsApp in their English language learning. The second instrument used in the present paper was a pre-test (Appendix B). The third instrument was a post-test (Appendix C). Both tests were meant to compare and measure the development of the students' reading skills.

\subsection{Procedure}

This research involved multiple steps and took 12 weeks to complete. In the first week, all the participants were informed about the conduct of the study, its objectives and implications, and were divided into two groups. The control group would learn in the conventional way, while the experimental group was subjected to the combination method of learning (WhatsApp and the conventional way). Both groups took a pre-test (Appendix B) to determine their actual level of proficiency in English before implementing the experiment. Then, and still before starting the experiment, only the experimental group was interviewed by taking a focused group interview (Appendix A) where the students were divided into groups of five in order to elicit their views about the English language and the learning of it using mobile phone and associated technology.

During the ten weeks that followed, both groups typically attended two English classes every week, where the teacher introduced them to a new list of vocabulary items each week. First, the students were asked to read the new list silently. Then, the teacher read the list, and the students were instructed to repeat the reading. After class, only the experimental group was sent the same list of words via WhatsApp, supported by an audio clip of the word list. These students were asked to read the list, listen to the sound clip, practice, and then record their own sound clip of the list and send it to their teacher via WhatsApp. At the beginning of the next class, the teacher listened to the sent sound clips of students to evaluate and mark his students' performance. He chose the best recorded sound clip and played it during class to motivate his students. The overall progress of each student was recorded in a progress report each week.

Week 12 was devoted to administering the same focused group interview (Appendix A) to the experimental group in order to elicit their beliefs and views about the incorporation of WhatsApp in language learning after the experiment. In the same week, all the participants, namely both groups, sat for the post-test (Appendix C) to measure and compare their language improvement in terms of their reading skills.

\section{Findings and Discussions}

The purpose of this research was to identify the impact of using WhatsApp on improving the reading skills of the participants. To this end, the same pre-test and a post-test were applied for a control group (conventional instruction with no use of WhatsApp) and an experimental group (use of WhatsApp), with a particular focus on the number of mistakes made by each member in the two groups. The results are shown in Table 1. 
Table 1. Comparison of pre-test and post-test results between the experimental group and the control group

\begin{tabular}{|c|c|c|c|c|}
\hline \multicolumn{3}{|c|}{ Experimental Group } & \multicolumn{2}{|c|}{ Control Group } \\
\hline Student & Pre-Test & Post Test & Pre-Test & Post Test \\
\hline 1 & 3 & 1 & 2 & 3 \\
\hline 2 & 4 & 2 & 4 & 3 \\
\hline 3 & 8 & 3 & 6 & 5 \\
\hline 4 & 6 & 1 & 6 & 7 \\
\hline 5 & 2 & 1 & 4 & 7 \\
\hline 6 & 5 & 2 & 5 & 5 \\
\hline 7 & 4 & 0 & 4 & 5 \\
\hline 8 & 6 & 2 & 4 & 6 \\
\hline 9 & 3 & 0 & 3 & 4 \\
\hline 10 & 4 & 2 & 6 & 3 \\
\hline 11 & 5 & 2 & 3 & 5 \\
\hline 12 & 4 & 1 & 5 & 6 \\
\hline 13 & 6 & 1 & 5 & 4 \\
\hline 14 & 3 & 0 & 6 & 4 \\
\hline 15 & 4 & 0 & 8 & 8 \\
\hline 16 & 6 & 3 & 5 & 2 \\
\hline 17 & 5 & 1 & 4 & 6 \\
\hline 18 & 3 & 0 & 7 & 7 \\
\hline 19 & 4 & 1 & 4 & 8 \\
\hline 20 & 5 & 0 & 4 & 5 \\
\hline 21 & 4 & 0 & 4 & 7 \\
\hline 22 & 1 & 1 & 6 & 5 \\
\hline 23 & 4 & 2 & 8 & 8 \\
\hline 24 & 3 & 0 & 5 & 4 \\
\hline 25 & 2 & 1 & 6 & 8 \\
\hline 26 & 4 & 0 & 3 & 5 \\
\hline 27 & 7 & 3 & 6 & 7 \\
\hline 28 & 4 & 1 & 6 & 3 \\
\hline 29 & 3 & 0 & 2 & 4 \\
\hline 30 & 4 & 2 & 4 & 5 \\
\hline Total & 126 & 33 & 145 & 159 \\
\hline
\end{tabular}

As indicated in Table 1, no significant difference was found in the number of mistakes made by the experimental group and the control group in the pre-test (126 vs. 145 respectively). This indicates that both groups shared the same proficiency level in English. However, a stunning difference was noted when comparing the number of mistakes of both groups in the post-test (33 vs. 159). This difference is mainly attributed to the implementation of WhatsApp, which was used solely by the experimental group. This finding is in accordance with the work of Amry (2013) and Alfaki and Alharthy (2014), who came to the conclusion that social network-aided learning overtakes the conventional way of learning. 


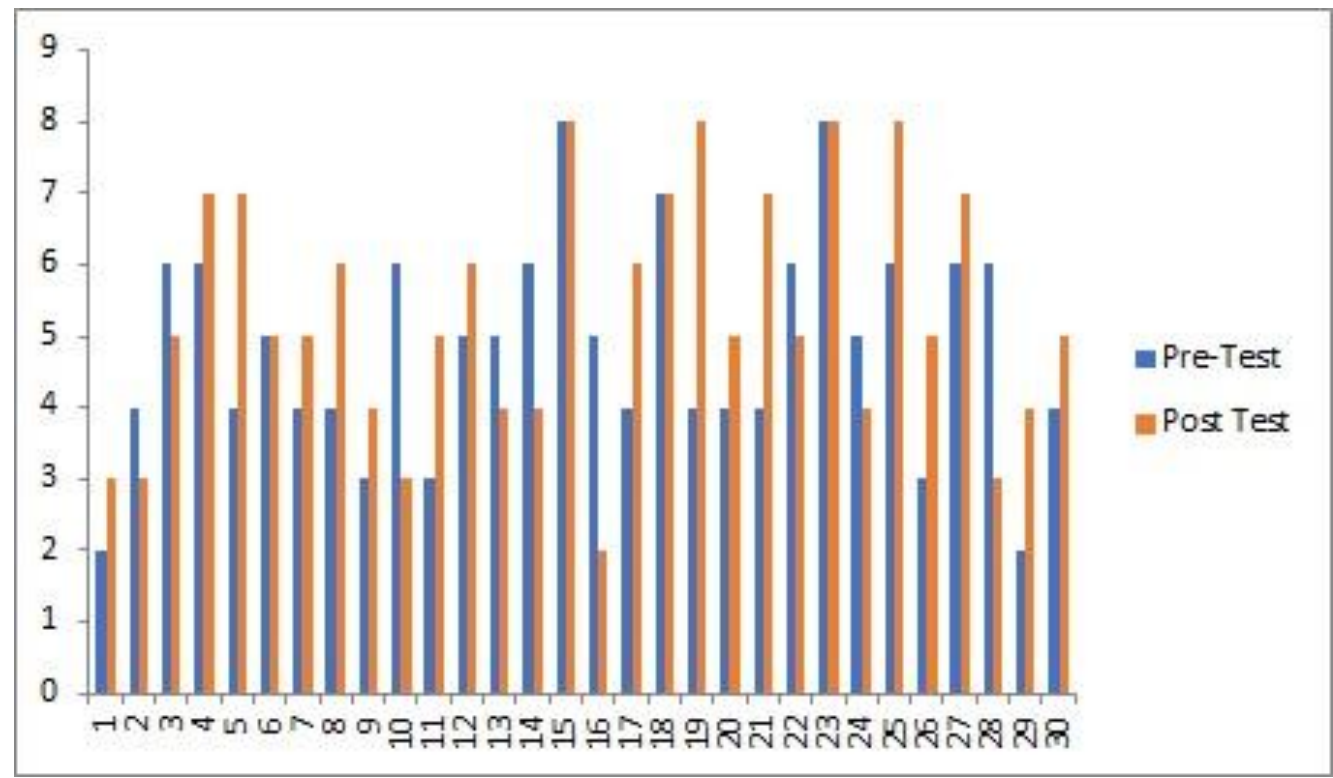

Figure 1. Number of mistakes made by the control group

Figure 1 displays the non-significant difference between the pre and pot tests results in the reading performance of the control group, who were learning English in the conventional way without the use of WhatsApp. It is clearly shown that the participants in the control group were unable to repeat the taught words properly and seemed to forget them altogether, which explains the rise in the number of mistakes from the pre-test (145) to the post-test (159).

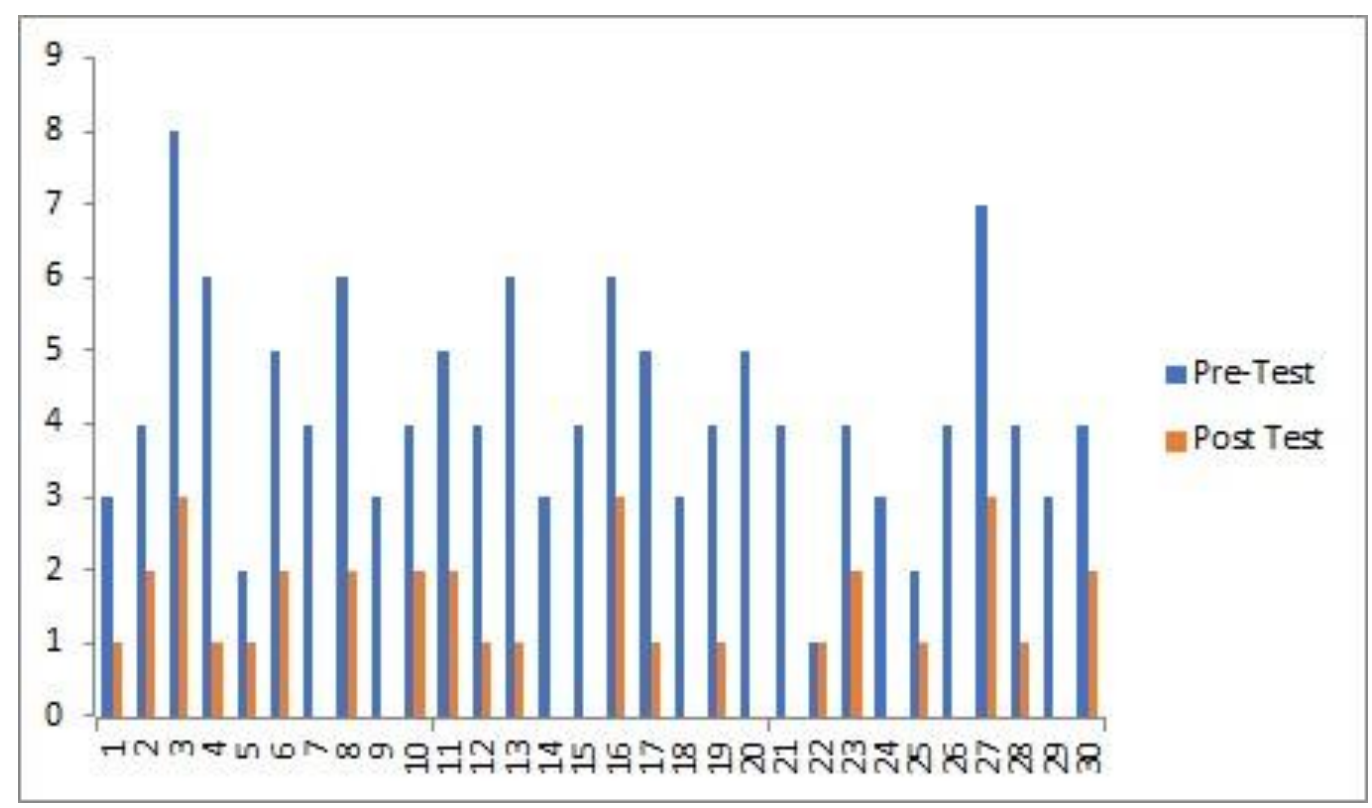

Figure 2. Number of mistakes made by the experimental group

A considerable drop in the number of mistakes made by the experimental group is noticeably displayed in Figure 2 when comparing their performance in the pre-test and the post-test (128 vs. 33). These results imply that the students significantly benefited from the implementation of WhatsApp in their language-learning process in terms of their 
reading skills. The evidenced enhancement in this skill is explained by the fact that the participants consistently sent their own recordings of the given words. This reveals that WhatsApp positively influenced the students' ability to participate and connect with peers online at any time. The language classrooms comprise large numbers of students, which prevents them all from participating and practicing their reading skills, but when WhatsApp becomes available, such problems are solved. This agrees with the findings of Rambe and Bere (2013) (as cited in Ta'amneh, 2017) as well as those of Ahmad et al. (2018), who came to the conclusion that the English learning process could be made more effective through the incorporation of such technological applications as WhatsApp than with the conventional method.

When it comes to the participants' perceptions of English language learning through the use of WhatsApp, this constitutes the second concern of this study. An intra-group (experimental) comparison was established between the participants' responses before and after the experiment. These respondents articulated very different attitudes, which were altered in favour of the use of WhatsApp after experiencing it in their learning of English.

Table 2. Focus group interview responses before the introduction of Whatsapp

\begin{tabular}{|c|c|c|c|c|c|}
\hline Seq & Statement & Choice & Frequency & Percentage & Common Comments \\
\hline \multirow{3}{*}{1} & \multirow{3}{*}{ Students' perception towards learning English } & Positive & 10 & $32 \%$ & \multirow{3}{*}{$\begin{array}{l}\text { 1. English is hard to learn } \\
\text { 2. What is goal of learning English } \\
\text { 3. I have tried to learn English but in vain }\end{array}$} \\
\hline & & Neutral & 2 & $9 \%$ & \\
\hline & & Negative & 18 & $59 \%$ & \\
\hline \multirow{5}{*}{2} & \multirow{5}{*}{ The most important language skill to learn } & Reading & 5 & $16 \%$ & \multirow{5}{*}{$\begin{array}{l}\text { 1. I want to speak in English } \\
\text { 2. I want to use English while traveling } \\
\text { 3. Everything is written in Arabic so why to } \\
\text { learn English } \\
\text { 4. To whom I can write in English no one } \\
\text { use it }\end{array}$} \\
\hline & & Writing & 4 & $13 \%$ & \\
\hline & & Listening & 0 & $0 \%$ & \\
\hline & & Speaking & 21 & $71 \%$ & \\
\hline & & & & & \\
\hline \multirow{6}{*}{3} & \multirow{6}{*}{$\begin{array}{l}\text { How to learn your preferred language skills } \\
\text { better }\end{array}$} & With my & 17 & $55 \%$ & \multirow{6}{*}{$\begin{array}{l}\text { 1. I watch English movies } \\
\text { 2. I watch English videos and clips on } \\
\text { YouTube } \\
\text { 3. Can't communicate in English } \\
\text { 4. Can't understand anything in English }\end{array}$} \\
\hline & & teacher & & & \\
\hline & & At home & 0 & $0 \%$ & \\
\hline & & practice & & & \\
\hline & & $\begin{array}{l}\text { Social } \\
\text { entertainment }\end{array}$ & 9 & $32 \%$ & \\
\hline & & $\begin{array}{l}\text { Studying } \\
\text { abroad }\end{array}$ & 4 & $13 \%$ & \\
\hline \multirow{4}{*}{4} & \multirow{4}{*}{$\begin{array}{l}\text { The idea of using WhatsApp in language } \\
\text { learning }\end{array}$} & Accessible & 12 & $39 \%$ & \multirow{4}{*}{$\begin{array}{l}\text { 1. I don't have my own smartphone } \\
\text { 2. My parents don't allow me to use } \\
\text { WhatsApp } \\
\text { 3. I don't know English how to use it }\end{array}$} \\
\hline & & Useful & 7 & $23 \%$ & \\
\hline & & Easy & 21 & $71 \%$ & \\
\hline & & & & & \\
\hline \multirow{4}{*}{5} & \multirow{4}{*}{$\begin{array}{l}\text { The students' beliefs about developing English } \\
\text { language skills through the WhatsApp }\end{array}$} & Positive & 4 & $13 \%$ & \multirow{4}{*}{$\begin{array}{l}\text { 1. It is not possible to learn through } \\
\text { WhatsApp } \\
\text { 2. It is not an easy idea } \\
\text { 3. I don't think that it will be effective }\end{array}$} \\
\hline & & Neutral & 3 & $10 \%$ & \\
\hline & & Negative & 23 & $77 \%$ & \\
\hline & & & & & \\
\hline
\end{tabular}


Table 3. Focus group interview responses after the introduction of Whatsapp

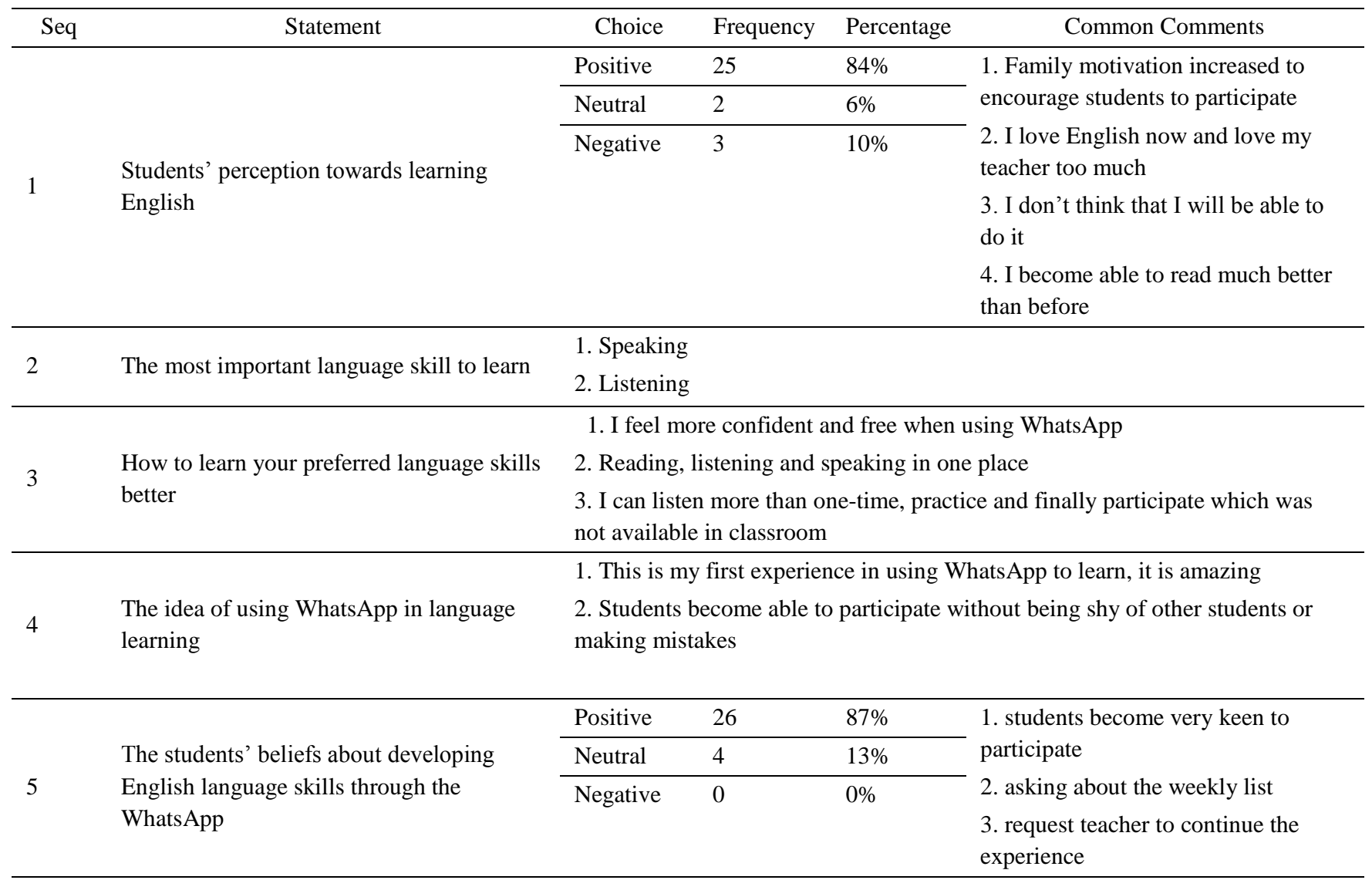

The participants' perceptions towards the English language after experiencing learning it through the use of WhatsApp were very positive, as they demonstrated a higher interest in and a readiness to learn it. One of the respondents related, "I love English now and love my teacher too much."

Statistically, $84 \%$ of these students held a favourable attitude towards the language. This percentage, however, did not exceed $32 \%$ before carrying out the experiment. This demonstrates the positive potential of WhatsApp's employment in the language classroom, which is in accordance with the results of Mbukusa (2018), who found a significant correlation between the students' interest in the English language and the use of WhatsApp, describing the latter as one of the most resourceful teaching tools that would attract learners and increase their contributions to the language-learning process. More interestingly, no negative responses were detected concerning the students' beliefs about developing English language skills through WhatsApp. By contrast, 87\% of them feel that WhatsApp could be helpful and useful in their learning and would improve their language skills. It is to be mentioned that this rate namely; $87 \%$ was limited to $13 \%$ before the employment of WhatsApp. These findings strongly agree with the work of Bere (2013), who argued that WhatsApp is liable to "create alternative dialogic spaces for student collaborative engagements in informal contexts, which can gainfully transform teaching and learning" (p. 544).

In the same vein, the positive attitudes that the participants showed towards the employment of WhatsApp in their learning may be attributed to the fact that this application provides them with the opportunity to express themselves freely in a non-restricted environment and removes the constraints to participation that characterize classrooms. Such a result is supported by comments voiced by some of the participants, such as, "I can listen more than one time, practice, and finally participate, which was not available in [the] classroom," and "students become very keen to participate." The same results were found by Riyanto (2013), who foregrounded the students' suggestion of WhatsApp as their most preferred mode of learning due to the bulk of attributes it is associated with. Moreover, the subjects demonstrated a high motivation to learn English supported by the use of WhatsApp. The same conclusion was reached by Ta'amneh (2017), Hamad (2017), and Justina (2016), who conveyed that the use of WhatsApp increased learners' motivation for language learning. 


\section{Recommendations}

Even though this study's focus was on reading, the speaking and listening skills were indirectly performed by the participants and thus their improvements were also assumed. This confirms the conclusion of several researchers, which is that the WhatsApp is one of the most effective mobile learning techniques to develop students' language skills. The writing skill, however, was discarded. Therefore, more focus on this skill is needed in order to examine the relationship between its improvement and WhatsApp and measure the effect of its use on enhancing this skill

Learners' preferences change rapidly, and so does technology with its unstoppable boom of applications. If WhatsApp today is the most favoured application among these learners, it may not be the case in the coming days, which urges consistent research that focuses on the analysis of those learners' needs in order to keep up with their varying requirements, attempt to satisfy them, and thus guarantee greater language attainment.

In another vein, teachers' presence to monitor and moderate learners' use of WhatsApp in a group setting is also highly recommended. This is conceptualized as teacher moderated synchronous mobile phone assisted learning (TMSMPAL). When applied, a more organized learning environment is nurtured and better language achievements take place (Sam, 2016). In addition, WhatsApp and other mobile applications may be considered by the teachers as up-to-date teaching tools that are liable to boost their learners' motivation and thus increase their learning. This, in turn, promotes these teachers' professional development and improves their teaching practices, which would contribute to the improvement of the learners' language performance and achievements.

WhatsApp, as the literature suggests, is believed to help learners become more confident in their use of English by experiencing the language in practice. The student-centeredness inherent in their moves and initiatives to perform the language also nurtures the students' motivation for learning. A great amount of research has been carried out to prove the positive influence of motivation on academic advances and the different variables that enhance it. Accordingly, follow-up research may centre around the investigation of the relationship between instant messaging applications and motivation.

\section{Limitations}

The present research is confounded by a number of issues. First, the conclusions drawn were based on performances and perceptions of male subjects only. A mixed population in the research would have yielded a more comprehensible account of the use of WhatsApp in language learning in the Saudi context. Second, the number of participants in the study was limited to 60 ; more subjects voicing their views may have led to different conclusions. Third, the whole study ranged over 12 weeks in only one establishment in the Kingdom of Saudi Arabia; this prevents the findings from being generalized. The same study could have been conducted to include a representative number of universities, which would confer more reliability on the research findings.

\section{Conclusion}

WhatsApp is a popular mobile application that is commonly used among students. Its popularity is attributed to the technological affordability of this application, which is easy to use in addition to being free. As such, its integrity in education has been strongly defended by many authors who have supported their defence with empirical research that has confirmed the significant attainments reached by language learners through the use of WhatsApp. Such results have also been backed by other researchers who focused on the students' perceptions towards the incorporation of WhatsApp in the curriculum, which were favourable and satisfactory. The present study lends support to the existing literature about the attributes of WhatsApp with a particular focus on the Saudi context. It investigated the use of WhatsApp among young Saudi EFL learners and showed results that were relatively positive in general. Among the findings were that this mobile application actually helped students improve their reading skills and that these learners held a favourable attitude towards the learning of English after the employment of WhatsApp.

Despite its recognized advantages, WhatsApp usage poses a few challenges that may hamper its appropriate employment in education. Such challenges involve the learners' misuse or abuse of this messaging application. Accordingly, academicians, pedagogists, and teachers are expected to consider such conditions in order to better reap its benefits and help their students in their language-learning process.

\section{References}

Ahmad, A., Tanduklangi, A., \& Miliha, L. (2018). The Effect of Using Whatsapp Messenger on Students' Speaking Achievement at the Second Grade Students of Madrasah Aliyah Negeri (MAN) 1 Kendari. Retrieved from ojs.uho.ac.id/index.php/JTO 
Ajid, H., Reni, R., Ynita, D., \& Dwi, S. (2018). The Use of WhatsApp in Collaborative Learning to Improve English Teaching and Learning Process. International Journal of Research Studies in Educational Technology, 7(1), 29-35.

Alfaki, I., \& Alharthy, K. (2014). Towards a Digital World: Using Social Networks to Promote Learner's Language. American International Journal of Contemporary Research, 4(10), 105-114.

Almekhalfi, A. G., \& Almeqdadi, F. A. (2010). Teachers' Perceptions of Technology Integration in the United Arab Emirates School Classrooms. Educational Technology and Society, 13(1), 165-75.

Alshammari, R., Parkes, M., \& Adlington, R. (2017). Using WhatsApp in EFL Instruction with Saudi Arabian University Students. Arab World English Journal, 8(4), 68-84.

Al- Issa, A. (2017). Qualities of the professional English language teacher educator: Implications for achieving quality and accountability. Cogent Education, 4(1), 1-17.

Amry, A. (2014). The Impact of Using WhatsApp Mobile Learning Activities on the Achievement and Attitudes of Online Students Using Mobile Devices at the University. European Scientific Journal, 10, 22.

Arya, A. (2017). The Role of Technology in Collaborative Learning. Academy Today. Retrieved from https://academytoday.co.uk/Article/the-role-of-technology-in-collaborative-learning

Bere, A. (2013). Using mobile instant messaging to leverage learner participation and transform pedagogy at a South African University of Technology. British Journal of Educational Technology, 44(4), 544-561.

Boyd, S. (2003). Are you ready for social software? Retrieved from http://www.stoweboyd.com/post/2325281845/are-you-ready-for-social-software

Cavas, B., Cavas, P., Karaoglan, B., \& Kisla, T. (2009). A Study on Science Teachers' Attitudes toward Information and communication Technologies in Education. The Turkish online Journal of Educational Technology, 8(2), 20-32.

Cetinkaya, L. (2017). The impact of Whatsapp Use on Success in Education Process. International Review of Research in Open and Distributed earning, 18(7), 59-74.

Chapelle, C. (2003). English language learning and technology. Amsterdam: John Benjamins Publishing Company.

Church, K., \& de Oliveira, R. (2013). What's up with WhatsApp? Comparing mobile instant messaging behaviors with traditional SMS. Proceedings of the 15th International Conference on Human Computer Interaction with Mobile Devices and Services (pp. 352-361). New York, USA: ACM. https://doi.org/10.1145/2493190.2493225

Forteza, F. R., \& Ortiz, R. S. (2015). Quality standards for the self- learning of languages through the internet. Procedia- Social and Behavioural Sciences, 187, 207-11.

Hamad, M. (2017). Using Whatsapp to enhance students learning of English language "Experience to share". Higher Education Studies, 7(4), 74-87.

Husain, N. (2015). Language and Language Skills. Retrieved from https://www.researchgate.net/profile/Noushad_Husain4/publication/274310952_Language_and_Language_Skil ls

Ismail, A. S., Almekhalfi, A. G., \& Al-Mekhalfy, M. H. (2010). Teachers' Perceptions of the Use of technology in Teaching Languages in United Arab Emirates Schools. International Journal for research in Education, 27, 37-56.

Jafari, S., \& Chalak, A. (2016). The role of WhatsApp in teaching vocabulary to Iranian EFL learners at junior high school. English Language Teaching, 9(8), 85.

Johnson, D. W., Johnson, R. T., \& Holubec, E. J. (1993). Circles of Learning: Cooperation in the Classroom (4th ed.). Edina, MN: Interaction Book.

Johnson, D. W. Johnson, R. T., \& Stanne, M. B. (2000). Cooperative Learning Methods: A Meta Analysis. Retrieved from https://www.researchgate.net/profile/David_Johnson50/publication/220040324_Cooperative_learning methods A_meta-analysis/links/

Justina, M. (2016). Use of Whatsapp to Enhance Reading and Writing Skills at Undergraduate College Level. Language in India, 16(11), 47-60. 
Kane, O. K., \& Harms, J. (2005). Getting started: a guide to collaboration in classroom. University of Hawaii at Manoa: The President's educational Improvement Fund.

Kant, R. (2018). WhatsApp Usage: Attitude and Perceptions of College Students. Journal of Education, 5(9), 27-37.

Kheryadi, K. (2018). The Implementation of "WHATSAPP" as a Media of English Language Teaching. Loquen, $10(2), 1-5$.

Mbukusa, N. R. (2018). Perceptions of Students' on the Use of Whatsapp in Teaching Methods of English as Second Language at the University of Namibia. Journal of Curriculum and Teaching, 7(2), 112-19.

Mustafa, H. R., Sain, N., \& Abdul Razak, N. Z. (2012). Using Internet for Learning Vocabulary among Second Language Learners in a Suburban School. Procedia-Social and Behavioural Sciences, 66, 425-431.

Muthaiyan, M., \& Kanchana, K. (2016). A Study on Developing Reading Skills of Engineering Students through WhatsApp as Motivational. International Journal of English Research, 2(3), 1-04.

Mwakapina, J., \& Mhandeni, A. (2016). WhatsApp Mobile Tool in Second Language Learning: Opportunities, Potentials and Challenges in Higher Education Settings in Tanzania. International Journal of English Language Education, 4(2), 70-90.

Ramakrishnan, N. (2017). Use of WhatsApp for English Language Proficiency among.ED. Trainees. International Journal of Research - Granthaalayah, 5(9), 1-6.

Sam, P. (2016). Learning beyond the Classroom through Whatsapp: An Informal Channel to Motivate Learners to stay Connected. Asian Journal of Research in Social Sciences and Humanities, 6(9), 1826-1833.

Ta'amneh, M. (2017). The Effect of Using "Whats App Messenger" in Learning English Language among University Students. International Journal of Humanities and Applied Social Science, 2(2), 15-22.

Wainwright, A. (2013). 10 Reasons Today's Students Need Technology in the Classroom. Securedge Networks. Retrieved from http://www.securedgenetworks.com/blog/10-Reasons-Today-s-Students-NEED-Technology-in-the-Classroom

Zahnle, N. E. (2016). Effects of Cooperative Learning on Academic Outcomes in a Diverse Laboratory Science Undergraduate Course (Unpublished master's thesis).University of Minnesota Duluth, the United States. 


\section{Appendices}

Appendix A. Focus group interview checklist

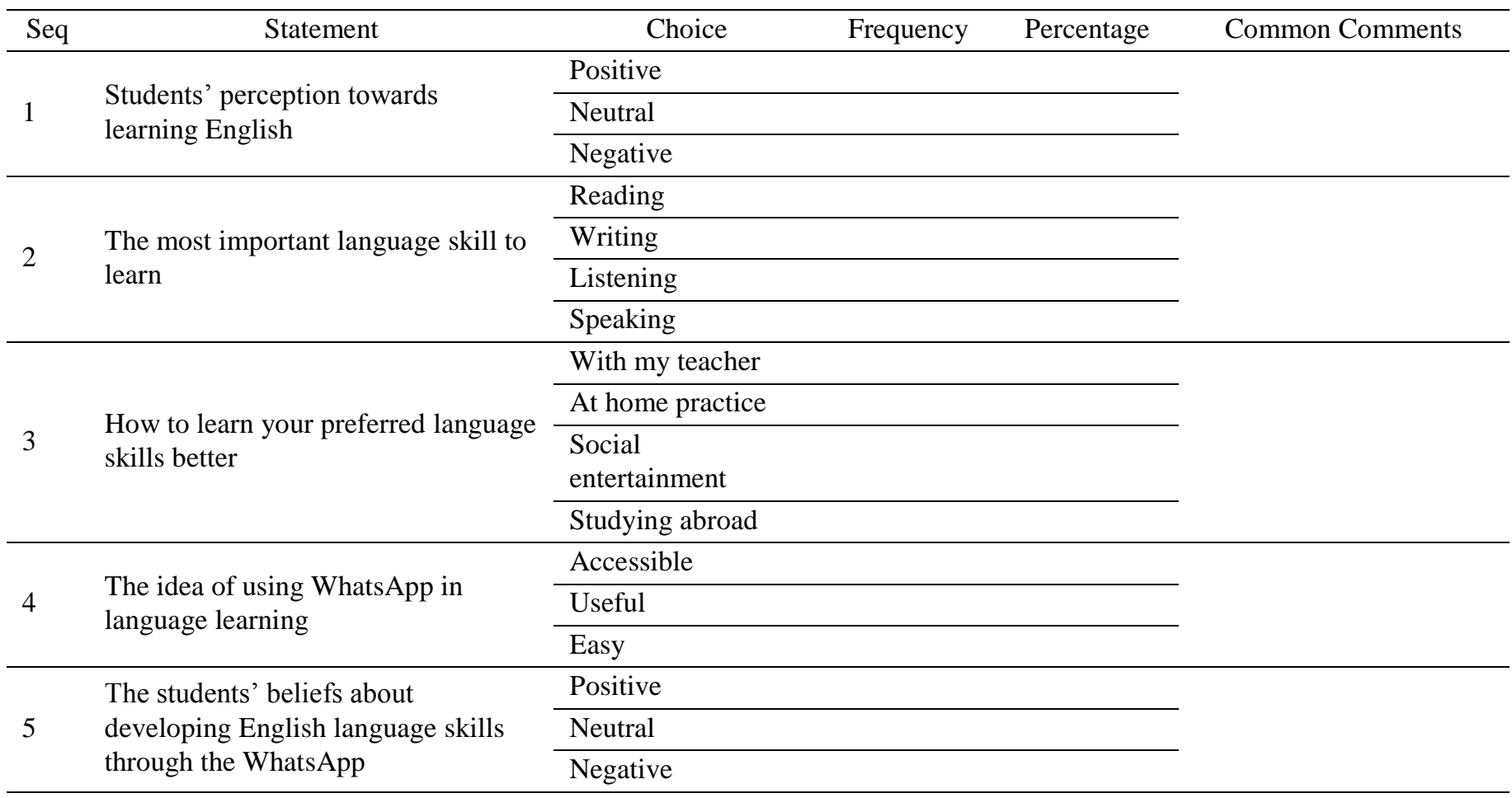

\section{Appendix B. Pre-Tests}

\begin{tabular}{cc}
\hline Seq. & Word \\
\hline 1 & Eye \\
\hline 2 & Money \\
\hline 3 & Place \\
\hline 4 & System \\
\hline 5 & Stand \\
\hline 6 & Mean \\
\hline 7 & Drive \\
\hline 8 & Different \\
\hline 9 & Important \\
\hline 10 & Strong
\end{tabular}




\section{Appendix C. Post-Tests}

\begin{tabular}{cc}
\hline Seq. & Word \\
\hline 1 & Break \\
\hline 2 & Experience \\
\hline 3 & Crowd \\
\hline 4 & Appointment \\
\hline 5 & Confidence \\
\hline 6 & Employee \\
\hline 7 & Improve \\
\hline 8 & Disappear \\
\hline 9 & Environmental \\
\hline 10 & Encouraging
\end{tabular}

\section{Appendix D. Weekly New Vocabulary Lists}

\begin{tabular}{cc}
\hline & Week 1 \\
\hline Seq. & Word \\
\hline 1 & Course \\
\hline 2 & Degree \\
\hline 3 & Research \\
\hline 4 & Term \\
\hline 5 & Break \\
\hline 6 & Arrange \\
\hline 7 & Attempt \\
\hline 8 & Discuss \\
\hline 9 & Environmental \\
\hline 10 & Practical
\end{tabular}

\begin{tabular}{cc}
\hline \multicolumn{2}{c}{ Week 2} \\
\hline Seq. & Word \\
\hline 1 & Details \\
\hline 2 & Encourage \\
\hline 3 & Manage \\
\hline 4 & Topic \\
\hline 5 & Experience \\
\hline 6 & Expect \\
\hline 7 & Experience \\
\hline 8 & Quiet \\
\hline 9 & Specific \\
\hline 10 & Equal \\
\hline
\end{tabular}

\begin{tabular}{cc}
\hline \multicolumn{2}{c}{ Week 3} \\
\hline Seq. & Word \\
\hline 1 & Qualification \\
\hline 2 & Training \\
\hline 3 & Border \\
\hline 4 & Channel \\
\hline 5 & Crowd \\
\hline 6 & Force \\
\hline 7 & Improve \\
\hline 8 & Manage \\
\hline 9 & Single \\
\hline 10 & Academic
\end{tabular}

\begin{tabular}{cc}
\hline \multicolumn{2}{c}{ Week 4 } \\
\hline Seq. & Word \\
\hline 1 & Ground \\
\hline 2 & Location \\
\hline 3 & Passenger \\
\hline 4 & Weapon \\
\hline 5 & Crew \\
\hline 6 & Complain \\
\hline 7 & Grow \\
\hline 8 & Outstanding \\
\hline 9 & Impossible \\
\hline 10 & International \\
\hline
\end{tabular}

\begin{tabular}{cc}
\hline \multicolumn{2}{c}{ Week 5 } \\
\hline Seq. & Word \\
\hline 1 & Appointment \\
\hline 2 & Flight \\
\hline 3 & Impact \\
\hline 4 & Reputation \\
\hline 5 & Rise \\
\hline 6 & Last \\
\hline 7 & Share \\
\hline 8 & Solve \\
\hline 9 & Unlikely \\
\hline 10 & Unusual \\
\hline
\end{tabular}

\begin{tabular}{cc}
\hline \multicolumn{2}{c}{ Week 6 } \\
\hline Seq. & Word \\
\hline 1 & Surface \\
\hline 2 & Action \\
\hline 3 & Activity \\
\hline 4 & Confidence \\
\hline 5 & Difference \\
\hline 6 & Disappear \\
\hline 7 & Land \\
\hline 8 & Damage \\
\hline 10 & Destroy \\
\hline
\end{tabular}




\begin{tabular}{cc}
\hline \multicolumn{2}{c}{ Week 7 } \\
\hline Seq. & Word \\
\hline 1 & Education \\
\hline 2 & Electricity \\
\hline 3 & Employer \\
\hline 4 & Employment \\
\hline 5 & Employee \\
\hline 6 & Distinguish \\
\hline 7 & Measure \\
\hline 8 & House \\
\hline 9 & Relatively \\
\hline 10 & Slow
\end{tabular}

\begin{tabular}{cc}
\hline \multicolumn{2}{c}{ Week 8 } \\
\hline Seq. & Word \\
\hline 1 & Improvement \\
\hline 2 & Investigation \\
\hline 3 & Scientist \\
\hline 4 & Authority \\
\hline 5 & Touch \\
\hline 6 & Afford \\
\hline 7 & Argue \\
\hline 8 & Encouraging \\
\hline 9 & sensitive \\
\hline 10 & Ancient
\end{tabular}

\begin{tabular}{cc}
\hline \multicolumn{2}{c}{ Week 9} \\
\hline Seq. & Word \\
\hline 1 & Achievement \\
\hline 2 & Cash \\
\hline 3 & Change \\
\hline 4 & Branch \\
\hline 5 & Finances \\
\hline 6 & Demand \\
\hline 7 & Insert \\
\hline 8 & Issue \\
\hline 9 & Conventional \\
\hline 10 & Massive
\end{tabular}

\begin{tabular}{cc}
\hline \multicolumn{2}{c}{ Week 10 } \\
\hline Seq. & Word \\
\hline 1 & Aspect \\
\hline 2 & Body \\
\hline 3 & Equipment \\
\hline 4 & Requirement \\
\hline 5 & Administration \\
\hline 6 & Preserve \\
\hline 7 & Reduce \\
\hline 8 & Available \\
\hline 9 & Disabled \\
\hline 10 & Unattended \\
\hline
\end{tabular}

